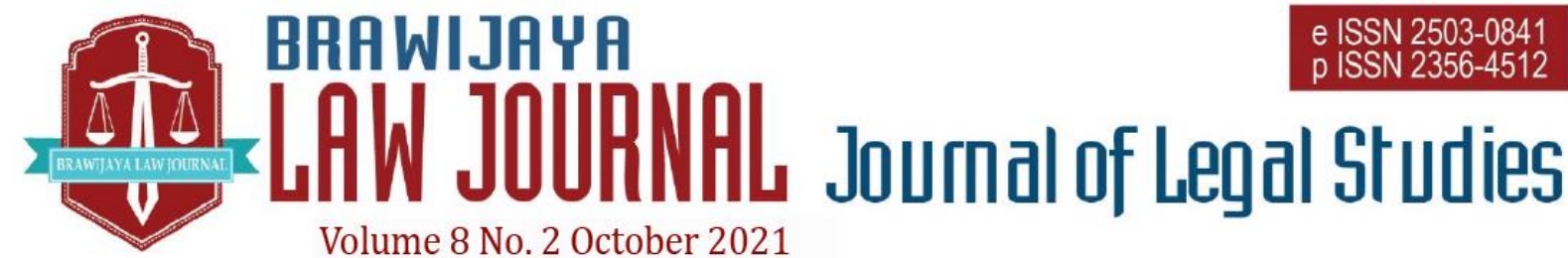

Nationally Accredited No. 30/E/KPT/2018 Dated 24th October 2018

This work is licensed under a Creative Commons Attribution-NonCommercial 4.0 International License

\title{
The Politics of Indonesia's Decentralization Law Based on Regional Competency
}

\author{
Ngesti Dwi Prasetyo*, Moh. Fadli, Tunggul Anshari SN, \\ Muchamad Ali Safa'at
}

\author{
Fakultas Hukum, Universitas Brawijaya \\ *Email: ngesti78@gmail.com
}

Submitted: 2021-06-25 | Accepted: 2021-09-22

\begin{abstract}
Local governments have undergone various regulatory developments since Indonesia's independence 75 years ago. Various aspects underlying the development and changes in local government policies can be analyzed using several approaches, such as historical, philosophical, and sociological. This paper will discuss how the legal politics of the development of local government implementation, especially in terms of decentralization. Furthermore, the author will explain about the opportunities for implementing decentralization based on regional capacity to promote welfare of society. This research is normative juridical research using historical approach, conceptual approach, and legal approach. It can be said that the implementation and development of local government implementation is strongly influenced by various aspects other than the legal factor itself. Furthermore, there is still the possibility of implementing decentralization based on regional capacity as an effort to promote social welfare.
\end{abstract}

Keywords: decentralization, regional competence, legal politics

\section{INTRODUCTION}

In Indonesia, the discourse about the appropriate form of a constitution began more than 75 years ago. This discourse begins with a discussion of the many regulatory processes that control the decentralized government paradigm. The dynamics are driven by a variety of philosophical rationales. For instance, the selection of decentralized models occurred following regime changes that exposed the void of power and encouraged other politicians and their groups to impose greater autonomy, or democratization that could increase the relevance of decentralization for the people, mobilizing grassroots support, etc. ${ }^{1}$ Apart from the pressures and political realities outlined above, intellectual disputes on the need or otherwise of decentralization also have a considerable impact. Differences in theoretical perspectives can influence

1 Muhammad Noor, Acknowledging the decentralization of Indonesia, (Interpena, 2012), pp. 52 
attitudes toward decentralization and the decentralization implementation strategy.

Indonesia as a country still in the process of developing its constitutional structure is frequently volatile. This dynamic is represented in Indonesia's legal politics of decentralization. The relationship between legal politics and decentralization in Indonesia paints a picture of the evolution of the law dictating how decentralization is to be implemented in all applicable laws and regulations in Indonesia.

Since the 1950s, Hennry Maddick has laid the groundwork for decentralization, which was later critiqued by Amy Upton Nolan $^{2}$ in his thesis on the evolution of decentralization. Nolan emphasized in his article Hennry Maddick's assertion that the essence of decentralization was an umbrella of deconcentration and devolution (decentralization). The second Islah is denoted by the following: First, deconcentration is "the delegation of authority adequate for the discharge of specified functions to staff of a central department who are situated outside the headquarters"; Second, Devolution or Decentralization is, "the legal conferring of powers to discharge specified or residual functions upon formally constuted local authories." 3

Figure 1 illustrates the development or dynamics of decentralization implementation in each set of laws and regulations. According to the Figure 1, prior to the 1945 Constitutional amendments, the arrangement of regional government evolved significantly since the establishment of the
Unitary State of the Republic of Indonesia to the enactment of Law Number 5 of 1974 concerning the Principles of Government in the Region. It is crucial to emphasize that decentralization policies can also be influenced by external pressures and political circumstances. As a result, each law is philosophically and sociologically distinct in terms of its formulation and concept of administering regional government's affairs. The formulation and concept developed in response to the social conditions of the time period in which it lived. One of the unresolved issues that will continue to haunt regional governance's legal politics is the suspicion that regional autonomy will result in disintegration. ${ }^{4}$

According to the preceding presumption, the requirement for a reappraisal is tied to how Indonesia's legal politics of decentralization operate. Adjustments are hoped to be made under the guise of regional competence. According to John M. Cohen and Stephen B. Peterson, the fundamental competency framework identifies decentralization through 6 (six) distinct methods, namely: ${ }^{5}$

1) Basic of historical origins (based on history);

2) By hierarchy and function (based on hierarchy and function);

3) By problem being addressed and the values of the investigation (based on suspicions and an investigation of values);

4) Focus on patterns of administrative structures and functions that are responsible for the production and

Law, Islamic University of Indonesia, 2001), pp. 4.

5 John M Cohen and Stepen B. Peterson, Adminitrative Desentralization, (Kumarian Press, 1999), pp. 20-22.

4 Bagir Manan, Welcome to dawn of regional autonomy, (Center for Legal Studies, Faculty of

2 Henry Maddick, Democracy Decentralization, and Development, (London: Asia Publishing House, 1966), pp.23 
provision of collective goods and services (concentrated on the patterns of administrative structures and functions that are accountable for the results and provision of goods and services);
5) Typically based on the experience of a single country (the type defined by the experience of a particular country); and
6) On basis of objectives (selected for the purposes).

Figure 1 Development of Decentralization Policy and Regulation in Indonesia

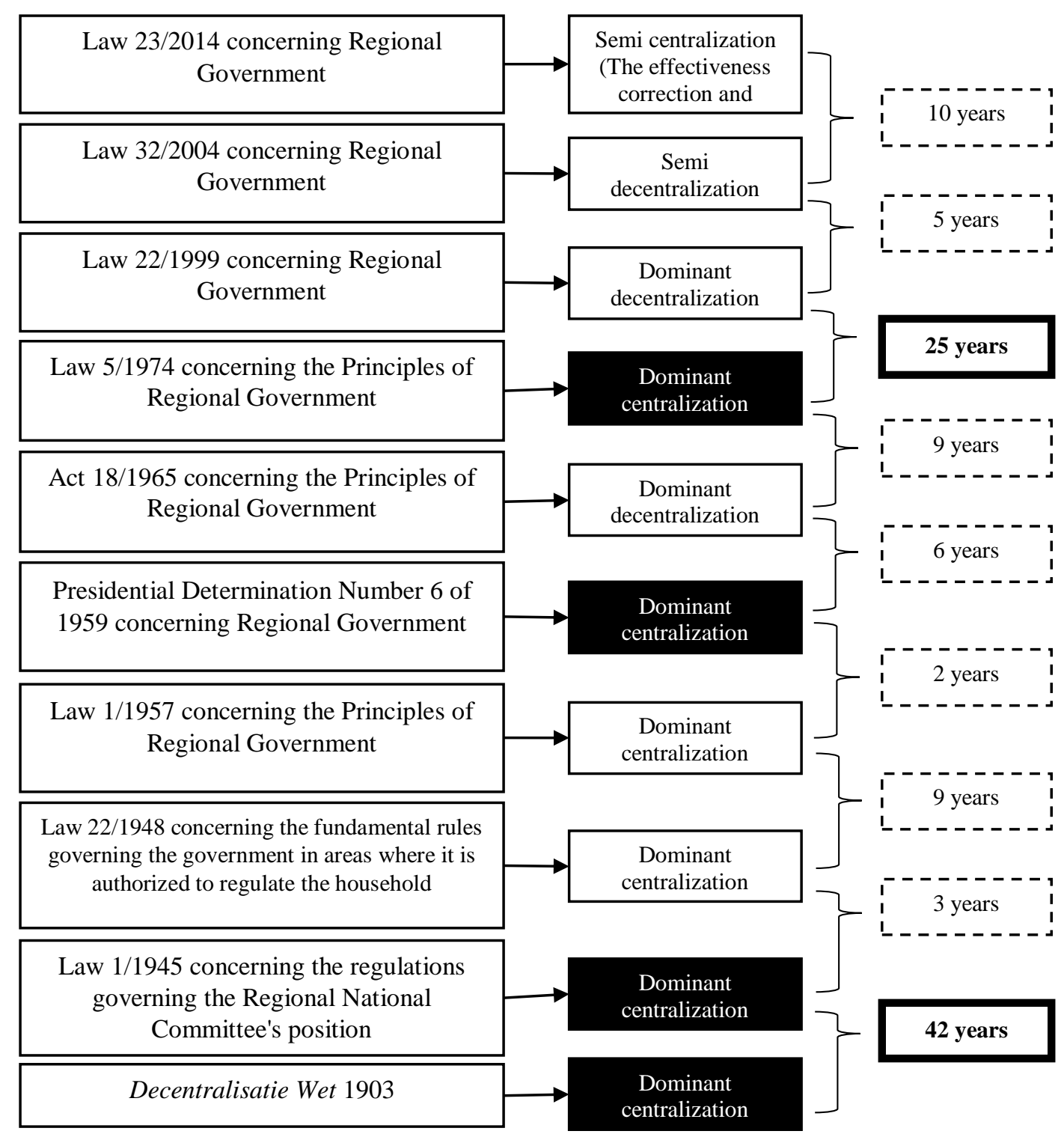

Source: secondary material of legal law, processed 2021 
This regional competency framework is also expected to be able to answer several objectives from decentralization formulation, namely for social welfare. Social welfare aspects cannot be separated from social justice based on John Rawls in his book $A$ Theory of Justice ${ }^{6}$, explaining the theory of social justice as the Difference Principle and The Principle of Equality of Opportunity. The essence of the distinct principle "prinsip pembeda" is that the social and economic disparities must be structured in a way that benefits those deemed disadvantaged, which in this context refers to someone who does not have the same possibility or opportunity in his attempts to get fundamental requirements. While the essence of the principle of equality of opportunity means that the party who has the smallest opportunity to achieve a welfare needs a special protection. ${ }^{7}$

According to Rawls in "Theory of Social Justice", the unequal situation in this socioeconomic sector must be structured in a way that benefits the weak parties. The enforcement enforcement program that is populist in nature must adhere to two principles of justice, namely providing equal rights and opportunities for basic freedom and then reorganizing the socioeconomic divide in such a way that there is reciprocity that benefits both lucky and unlucky parties. So that the predicted decentralization map based on the competence model may supply an aspect of "The Distinct Principle," this area is predicted to benefit the greatest number of regions with the most adverse conditions. According to the statement above, the focus of this study is on how does legal politics the development of local government implementation, especially in

6 John Rawls, Theory of Social Justice, H. Gene Blocker (ed) (Ohio: Ohio University, 1980), pp. 59. terms of decentralization. Furthermore, the author will explain the opportunities for implementing local capacity-based decentralization for the welfare of the community.

\section{LEGAL MATERIALS AND METHODS}

This article discusses the politics of regional competency-based decentralization law, with an emphasis on the formation of laws regulating regional government and the process by which authority is distributed between the central and regional governments in unitary state-related areas. Furthermore, this article explores regional opportunities that serve as the foundation for decentralization with the intention of representing the community's spirit and needs and increasing community engagement in development.

This research was conducted through the normative juridical method utilizing 3 (three) approaches, namely the historical approach, the conceptual approach, and the Statue Approach. The researchers took a historical approach in analyzing the evolution of legislation pertaining to regional government. The researchers employ a conceptual framework to analyze the implementation of regional competencybased decentralization concepts. The legislation approach is used to analyze legislation at all levels, from the fundamental principles of the Constitution and Law to Government Regulations and other implementing regulations that pertain to the subject of this article.

As with other normative studies, this article draws primary law material from 7 Ibid., pp. 230. 
legislation, including Law Number 23 of 2014 concerning Regional Government and related implementing regulations. Furthermore, the researchers consult secondary legal materials in the form of books, papers, comprehensive manuscripts, studies published by government and nongovernmental organizations, and other literature that can bolster this writing about concepts, theories, principles, and standards, particularly in the context of regional government and others who are closely related to the paper's theme. Along with these two legal documents, the researchers needed tertiary legal sources in the shape of dictionaries, both Thursday law and a language dictionary that will aid them in the process of developing arguments for this article.

\section{RESULT AND DISCUSSION} Historical, philosophical, and sociological studies of regional competency-based decentralization legal politics in Indonesia a. History

Throughout the history, the dynamics of trial and error in the legal politics of decentralization in our constitutional system have seen ups and downs. As stated in Article 18 of the 1945 Constitution, Indonesia is divided into large regions and small areas, each of which has the right to selfsufficiency, also known as autonomy. Autonomy refers to a lower government's ability to control and administer certain government functions. Government issues that can be handled and administered freely and independently will be referred to as autonomous. ${ }^{8}$ For this reason, founder of the Unitary State of the Republic of Indonesia long ago had been legally thought about

8 Muhammad Yamin, Proclamation and Constitution of the Republic of Indonesia, (Gahlia Indonesia, 1982), pp. 145 regional government. Therefore, the issue of regional autonomy must be realized in the framework of the unitary state as mandated by Article 18 of the 1945 Constitution, the substance:

"The division of the Indonesian region for large and small regions with the form of the composition of its government is determined by the law on the basis of 6the provision of the state government and the rights of origin in a special area."

There is an attraction in the state's life as part of the legal historical documents to implement Article 18. Law is not an end in itself, but rather a means to an end. ${ }^{9}$ In order to comprehend autonomy, we must first understand its purpose. The term "autonomy" can be defined in two ways: in the broad sense, it encompasses co-administration, and in the restricted sense, it excludes coadministration activities.

After the Old Order government fell and was replaced by the New Order government, Law Number 5 of 1974 was formed about the principal in the region. The formation of the law politically is the impact of legal history due to Law Number 22 of 1948 concerning the determination of the main rules regarding its own government in regions that are entitled to regulate their own household made during the revolutionary period accompanied by pressure from Dutch colonizers, where at that time the Dutch still often conducted his efforts to maintain colonialism in Indonesia. After the end of the Dutch colonialization and the enactment of the 1950 UUDS (Temporary Constitution 1950), the government still used Law Number 22 of 1948 concerning the determination of the main rules regarding its

9 Sunaryati Hartono, Legal Politics Towards A National Legal System (Alumni, 1991), p. 11 
own government in regions entitled to regulate their own household.

On January 17, 1957, Law Number 1 of 1957 was promulgated, outlining the fundamental principles of regional governance. This is the statute that pioneered the concept of true autonomy. Additionally, this law clarifies that there is no clear explanation or divide between central and regional governments, with being tough and rigid if specifics of authority or affairs between the central and regional governments are involved. ${ }^{10}$

After roughly 11 years of application of Law No. 1 of 1957, on July 23, 1974, promulgated Law No. 5 of 1974 about the Principles of Regional Government, we can conclude that this law is a regional government law of the new order. The law is perceived as not explicitly controlling the division of powers between the central and regional governments, as this division will be further defined in Government Regulations. Additionally, this law is highly influenced by centralism, as the central government has the ability to decentralize the functions supplied by the central government to the regions. On the regional level, elections for regional heads lacked democracy as well, as they were submitted to the Regional People's Representative Council without a direct election system.

After 25 years of applying Law Number 5 of 1974 following the fall of the New Order regime, the new administration felt it as necessary to amend Law Number 5 of 1974. It promulgated Law No. 22 of 1999 about Regional Government, which has the effect of repealing Law No. 5 of 1974. When the long trip of Law Number 5 of 1974 is evaluated in relation to the legal evolution of regional autonomy, it becomes a logical thing to do to amend the law. ${ }^{11}$

Regional Government Law No. 22 of 1999 promulgated on May 7, 1999 and legally official regional autonomous service can be expected to be in accordance with the mandate of the state of Indonesia's containment, thereby improving people's welfare. However, there are still others who face legal penalties under Law No. 22 of 1999, which establishes numerous petty kingdoms in the area. This is because the law promotes company expansion into new areas with the primary objective of funneling funds to the regions, establishing monopolies on mining concessions in the regions, and imposing high taxes on regional income interests. As a result, this encourages oligarchs and political clients to decentralize. $^{12}$

In light of these circumstances, the administration considers the necessity of amending Law Number 22 of 1999. On October 15, 2004, the government promulgated Regional Government Law No. 32 of 2004. The positive direction indicated by this law is the implementation of regional autonomy with the goal of accelerating the realization of community welfare by increasing regional competitiveness while taking into account the principles of democracy, equity, justice, privileges, and area specificity within the Unitary State of the Republic of Indonesia system. Additionally, the law encourages

Regional Government Legal History' (2013) Vol. 6 No.7 Journal of Inovatif, pp. 48

12 Wasisto Raharjo Jati, 'Regional Autonomy Paradigm Inconsistency in Indonesia: Cultural and Decentralization Issues', (2012), Volume 9 No.4, Journal of Konstitusi, pp. 743-769 
autonomous regions to be able to electrocertically expand their potential and diversity, as well as give financial autonomy. Considering its progress, Law Number 22 of 1999 did not provide enhanced capability or regional dissolution for the province to exercise its autonomy. ${ }^{13}$

After 10 years of the application of Law Number 32 of 2004, the Act was amended by the introduction of Law Number 23 of 2014 concerning Regional Government. Although this law is still in its development stage, there is discussion about whether the newly determined laws are still better than Law Number 32 of 2004, or whether Law Number 23 of 2014 prefers Autonomy in terms of constitutionality and Reformation needs over the last decade. ${ }^{14}$

In the end, Law No. 32 of 2004 experienced a paradigm shift in Law Number 23 of 2014 concerning Regional Government that the fundamental shift between what was confirmed in the 1945 Constitution and Law Number 23 of 2014. In Article 18 paragraph (5) The 1945 Constitution is consistent as reaffirmed in the Regional Government Act 2004 Article 10 paragraph (2) that:

"In carrying out regional
government affairs, as defined
in paragraph (1), the regional
government has the broadest
autonomy to control and
manage regional government
matters based on the principles
of autonomy and co-
administration."

The regional government is the legal subject of the rules above since it administers the widestic autonomy in accordance with

13 Suharno, 'Critical Review of Law Number 32 of 2004 concerning Regional Government', (2004), Volume 1 No. 2, Journal of Civics, pp. 168-180

14 Hesti Armiwulan, 'Legal politics of regional government based on Law Number 23 of 2014 in terms of institutions and the relationship between the authority of the regions in Inna Junaenah et. al., the concept of autonomy and the responsibility of co-administration established by the Republic of Indonesia's laws in 1945. Meanwhile, under Law No. 23 of 2014 on Regional Governments, which was enacted by the government, the focus shifted to the government. This can be gained by the following provisions of Article 5:

(1) The President of the Republic of Indonesia holds executive authority in accordance with the Republic of Indonesia's 1945 Constitution;

(2) Government Authority, as defined in paragraph (1), is manifested in a variety of government matters;

(3) The President is helped in conducting government affairs, as defined in paragraph (2), by the minister who arranges some government matters; and

(4) Government affairs, as defined in paragraph (2), are carried out in the region through decentralization, deconcentration, and coadministration.

The article unequivocally adopts the fundamental principles outlined in Law No. 5 of 1974 regarding the region's primary points of government. The title of the law indicates that it regulates the President's authority as regional government organizers, not regional government itself. Although the term decentralization (and co-administration) was added at the conclusion of the formulation, the verse's meaning is identical to that expressed traditionally by Henry Maddick ${ }^{15}$, namely, "the delegation of authority adequate for discharge of specified functions to staff of a

\footnotetext{
Decentralization or re-centralization? Politics of Regional Government Law According to Law No. 23 of 2014 concerning Regional Government, (State Policy Study Center, 2015), p. 102.

15 Henry Maddick, Democracy Decentralization, and Development, (London: Asia Publishing House, 1966), p 44
} 
central department who are situated outside the headquarters" or government tends to centralize.

When the history of regional government laws is considered, it is clear that our subordinative system has seen its share of ups and downs. As previously stated, the decentralization model in Indonesia, also provided affirmation as a unitary state, even though the concept of model (Union) or unity has been completed, the model of government (whether decentralized or centralized) has not been completed. The completion of this unity or model of unity is based on the Feeting Fathers' legal politics, which upholds article 1 paragraph (1), which is consistently regulated in various legal products. ${ }^{16}$ The unitary state in question Article 1 paragraph (1) of the 1945 Constitution is a unitary state that applies the legal politics of decentralization as stipulated in the provisions of Article 18 of the 1945 Constitution. Conceptually, the unitary state can be distinguished in two forms;

(1) Unitary state with a centralized system.

(2) Unity countries with decentralized systems. ${ }^{17}$

As explained in the preceding chart, Indonesia was effectively faced with two options due to the unitary state structure of its government administration: centralisk or desentralisk. Both options are permissible and legitimate, with all of their associated benefits and drawbacks. Sentrisk is typically run on a country with a small territory, a homogeneous population, and a monarchical government. In France, the Netherlands, and Sweden, for example. Meanwhile, large countries with a diverse population, such as Indonesia, are better suited to decentralization. Thus, we can say that the Founding Fathers' legal politics resulted in the formulation of Article 18 of the 1945 Constitution. There is only one thing that has been expressly forbidden in the Unitary State of the Republic of Indonesia, which is also central region. ${ }^{18}$ To analyze decentralization, we will use six (six) approaches, namely: ${ }^{19}$

1) Basic of historical origins (based on history);

2) By hierarchy and function (based on hierarchy and function);

3) By problem being addressed and the values of the investigation (based on problems that arise and investigating values);

4) fovis on patterns of administrative structures and functions that are responsible for the production and provision of collective goods and services (focused on patterns of administrative structures and functions responsible for the results and provisions of services and goods);

5) Typically based on the experience of a single country (the type based on a particular country's experience); and

6) on basis of objectives (based on the goal)
16 Minutes of the Workers Meeting of the People's Consultative Assembly (MPR) of the Republic of Indonesia, 1945 People's Consultative Assembly of the Republic of Indonesia, in 2002, HLM 38. There are several agreements, including (1) preserving and adhering to the 1945 opening, (2) preserving the Unitary State of the Republic of Indonesia, (3) preserving the Presidential System, (4) amending the 1945 Constitution using the adendum method, and (5) incorporating the basic norms contained in the 1945 Constitution's explanation into the 1945 Constitution's Articles.

17 Indra Perwira, op.cit., p. 436

18 See in the explanation of Article 18 of the 1945 Constitution before the amendment

19 John M Cohen and Stepen B. Peterson, Adminitrative Desentralization, (USA: Kumarian Press, 1999), pp.20-22. 


\section{b. Philosophical}

As previously stated, the unitary state had both decentralization and centralization conceptually. In a unitary state with a centralized system, the central government regulates and oversees everything in the country immediately, and the regions only carry out the central government's instructions. Whereas in a unitary state with a decentralized system, the depiction of areas with the ability and authority to regulate and manage their own households (regional autonomy) is not separated into autonomous regions. ${ }^{20}$ The understanding serves as an introduction to the fact that there is a legis ratio for why substituted scientific literature on decentralization includes regional autonomy as a necessary component, as regional autonomy is the essence of decentralization. ${ }^{21}$ However, the issue of consistency as a unitary state and applying this decentralization model based on historical perspectives remains immature.

Simply put, in the autonomy of the authority between the center and the region, including issues such as how government administration is distributed or how regional household affairs are determined. This criterion will reflect a degree of limited or extensive autonomy. It is capable of being classified as having limited autonomy if:

(1) First, Regional household affairs are classified categorically, and development is directed in specific directions.

20 Abdurrahman (Editor), Some Thoughts about Regional Autonomy. Media Sarana Press, Jakarta. 1987, p. 56

21 Look inside M. Laica Marzuki, Take A Look in The Realm of Law, the Secretariat General and Registrar's Office of the Constitutional Court of the Republic of Indonesia, Jakarta, 2006, p. 161

22 While the usual broad autonomy departure from principle: all government affairs basically become
(2) Second, If the supervision and supervision system is implemented in such a way that the autonomous region loses its ability to establish and manage regional households freely.

(3) Third, the financial relationship system between centers and regions raises issues such as the limitations of regions' initial financial capacity, thereby limiting regional autonomy. ${ }^{22}$

The emphasis on "broad autonomy," as described previously, is the primary impediment to the Indonesian state maintaining a (consistent) decentralization model. This is because the principle of "extensive autonomy" was confirmed and codified in Article 18 paragraph (5) of the 1945 Constitution of the Republic of Indonesia, which states that "the regional government exercises widestic autonomy, except for government affairs that are statutorily designated as central government affairs."

Philosophically, despite the fact that understanding broad autonomy becomes a polemic of interpretations about the constitution and its implementation law, at least in terms of the decentralization system, the 1945 Constitution established a constitutional foundation in Article 18, Article 18A, and Article 18b. The following principles are contained in these articles: ${ }^{23}$

a. The state's recognition and respect for units of customary law communities (kesatuan-kesatuan masyarakat hukum) and their traditional rights as

regional domestic matter, except determined as a central business. In modern countries, more - more if it is associated with the understanding of the country of welfare, government affairs cannot be recognized. In Bagir Manan, Welcome to The Arising of Regional Autonomy, the publisher of the Law Study Center, Yogyakarta, 2005, p. 37

23 Bagir Manan, Opcit, pp. 5-6 
long as they remain viable and in accordance with the community's development, as well as the unitary state principle of the Republic of Indonesia;

b. Regional principles regulate and administer government affairs in accordance with the autonomy and co-administration principles;

c. The principle of operating with the maximum possible autonomy;

d. The principles acknowledge and declare the existence of special and unique regional governments;

e. The Representative Agency's principle is directly elected in an election;

f. Central and regional relations must be conducted in an orderly and equitable manner;

g. The principle of delegation of authority between the central and local governments must account for regional uniqueness and diversity;

h. Financial relationships, public services, natural resources, and other resources between the central and regional governments are conducted fairly and in accordance with the law; and

i. Special or unique is the principle of recognition and respect for state government units.

Furthermore, understanding decentralization in Indonesia cannot be divorced from historical-philosophicalpolitical debates, as the experience of developing countries demonstrates that decentralization does not facilitate

\footnotetext{
${ }^{24}$ Haryanto, 'Future of Decentralization Politics in Indonesia: An initial study', (2016) Volume 9 No. 2 Government: Government Journal, p. 115

25 Ni'matul Huda, Law of Regional Government, (Bandung: Nusamedia, 2010), p. 1
}

"development" or democratic outcomes. The realization, numerous studies evaluating decentralization demonstrate that success stories about decentralization are uncommon and that decentralization is not an entirely effective strategy for poverty reduction. ${ }^{24}$ The level of implementation of regulations related to decentralization and regional autonomy historically since the beginning of the implementation of Law Number 1 of 1945 concerning the position of the Regional National Committee to Law Number 23 of 2014 concerning the Regional Government actually focused on the welfare frame of the community. In accordance with the mandate of the 1945 Republic of Indonesia, the local government is authorized to regulate and take care of government affairs according to the principle of autonomy and co-administration. Provincing of broad autonomy to the region is directed to accelerate the realization of community welfare through improving service, empowerment and participation of the community. In addition through extensive autonomy, the region is expected to increase competitiveness by paying attention to the principles of democracy, equity, justice, privileges and specificity and the potential and diversity of regions in the System of the Unitary State of the Republic of Indonesia. ${ }^{25}$

Moh.Hatta has also confirmed the understanding of this regional autonomy exercised in the interest of welfare on the basis of popular sovereignty or populism ${ }^{26}$ : "According to the people's sovereignty, the people have the right to determine their own fate not only at the government level, but also in each location (in the city, village and

26 Mohammad Hatta, Towards Indonesian independence: 1932-volume I, (Jakarta: Bulan Bintang, 1976), p.103. 
regions). Each fellowship has its own governing body (such as Gemeenteraad Provinciale Raad, and others). As a result, each segment or group of people becomes autonomous (creating and practicing its own rules and running the rules made by a higher board). Thus, it is not just a large fellowship that has the right to determine his or her own destiny, but all people, as well as every region of the country or group of people. Such details are critical, as the requirements of each region within a country vary.".

Figure 2. Decentralization concept in Indoensia

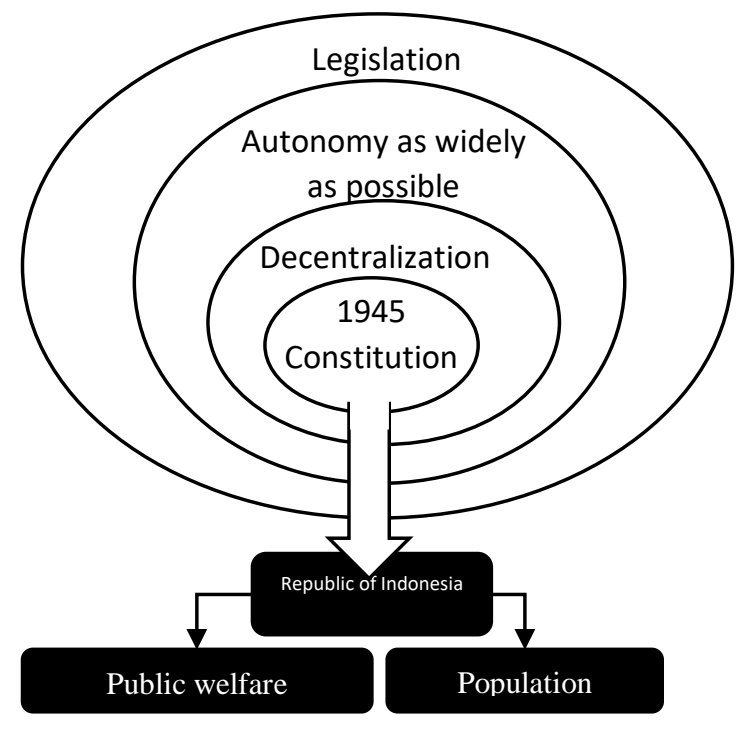

Based on the Figure 2, it is illustrated that the decentralized model mandating the existence of autonomy in Indonesia is not a regional rape process which in the sense of independence (separate sovereignty) or autonomy cannot be interpreted as the absolute freedom of an area because autonomy is a process to provide a process To the area to be able to develop in accordance with the potential they have, thus autonomy must be meaningful as a way to optimize all local potential, both nature, environment and culture. Furthermore, optimization is not exploitation, but a process that allows regions to develop themselves and change the lives of regional society to be better. $^{27}$

27 M.R. Khairul Muluk, Decentralization and Local Government, (Malang: Bayumedia Publishing, Cet 2, 2007), pp.10

28 Mardyanto Wahyu Tryatmoko, Mardyanto Wahyu Tryatmoko, 'Democratization of Problems in The

\section{c. Sociological}

Sociologically, as previously discussed in relation to the historical-philosophical aspects, the decentralization problem was caused by the surrender of the implementation of the authority distribution mandated by Article 18 paragraph (5), which stated that "the regional government exercises the greatest autonomy, except for central goverment affairs." Thus, in practice, the interpretation of the article's provisions frequently sparks controversy, particularly when it comes to enacting legislation that affects the decentralization model. ${ }^{28}$

The context of Indonesia's holding model of decentralization, dubbed asymmetrical decentralization, which

New Post-Order Era of Asymmetrical Decentralization', (2012), Volume 38 No. 2, Journal of Masyarakat Indonesia, pp. 269-296 
resulted in the emergence of a system of autonomy with distinct characteristics based on special provisions, is analogous to special autonomy. ${ }^{29}$ In the context of Indonesia's decentralization model implementation, an introduction to the autonomy system, which has distinct characteristics and is governed by its own legislation, including Aceh Province, Papua Province, Jakarta Special Capital Region, and Yogyakarta Special Region. As a result of Article 18B paragraph (1), the state recognizes and respects statutory special or special regional government units. As a result, a variety of factors have been used to justify the issuance of policies that provide specificity for regional government organization. For instance, Papua Province is a case study in terms of politics, economics, and natural resources. These factors arose as a result of a failure of development during the New Order regime, which resulted in the emergence of repressive patterns in the context of welfare

29 Ibid.

30 Papua, is a province that is part of Indonesia not together with other regions. Other areas have defaCto have become the territory of the Republic of Indonesia since August 17, 1945 or juridically from December 27, 1949 through the round table conference negotiations when the Dutch Government officially releases his colonies to the Government of the Republic of Indonesia, except New Gunea West or Irian Jaya, Now named Papua. Papua became part of the territory of Indonesia after through the PEPERA (people's opinion) whose results were acclamation to join the Republic of Indonesia on August 15, 1969, and officially since November 19, 1969 became the 27th province, after the results of the PEPERA were received by the General Assembly UN. The pepera held on August 15, 1969 was allegedly a source that supported the occurrence of conflict in Papua, in addition to the work contract conducted by the government with PT Freeport in 1967 which until now the conflict could not be completed. In the era of the New Order, the approach to resolving conflicts in Papua was carried out by centralized and repressive ways by making Papua a military operation area, due to the strengthening of the OPM (Papua Independence Organization). The conflict in Papua has not yet been over, although submission for the people of Papua, which would later undermine the purpose of Yatu community welfare decentralization. ${ }^{30}$

According to reports from the partnership team ${ }^{31}$ said that Papua was the most retarded province in Indonesia. In 1997 - prior to the Papuan crisis - the poverty rate was reported to be above $50 \%$, while the average national poverty rate was close to $14 \%$. Papua is Indonesia's province with the highest rate of poverty. In 1999, the percentage of the Papuan poor population was reported to be $54.75 \%$, maintaining Papua's status as the province with the largest poor population, followed by East Nusa Tenggara at $46.73 \%$ and Maluku at $46.14 \%$. In 2000 , poverty was reduced to $41.80 \%$, but remained the highest in Indonesia, followed by Maluku at $46.14 \%$ and East Nusa Tenggara at $36.52 \%$. Poverty and profound retardation in Papua were recognized as a failure of the New Order's approach to Papuan development. In comparison to other

after the collapse of the new Order of the central government used a more accommodating approach. For example, President Abdurrahman Wahid, on January 1, 2000 has apologized to the Papuan people for human rights violations carried out by the army in the past. The change in name of Irian Jaya became Papua based on the Decree of the Provincial Parliament of Irian Jaya No. 7 / DPRD / 2000 on August 16, 2000 concerning the return of Irian Jaya's name to Papua. HLM this is a driving device for Papuan special treatment as an autonomous region. Even during Gus Dur in power of the Morning Star flag could be raised beside the Red and White flag. But in the future Megawati there was a ban on raising the Morning Star flag. At this time the conflict was tapered, even leading to violence. View Sulardi, 2011, Researching autonomy to strengthen the NKRI, evaluation of the implementation of special autonomy in the frame of four pillars of life and state "organized by the People's Consultative Assembly of the Republic of Indonesia (MPR RI) in collaboration with the Development Center for Regional Autonomy (PP Otoda) Universitas Brawijaya ( UB), Malang, December 5 2011, p 5

31 Agung Djojosoekarto, et al, Papuan Special Autonomy Performance, (Jakarta: Updates on the Partnership for Governance in Indonesia, 2008) 
Indonesian regions, Papua has the most favorable environmental conditions. Internally, this retardation is caused by five major factors, namely that when it becomes a part of Indonesia:

1. The majority of Papuans live in conditions of retardation, or what academics refer to as primitivity;

2. There is no adequate physical infrastructure in terms of transportation and telecommunications, even at the most rudimentary level;

3. Low levels of welfare and health care as a result of a lack of education;

4. The region's limited capacity for human resources to enter directly into "machine" development that has a "mode" of the community, as in Java and other more advanced kawasans than Papua;

5. The lack of capability among the local elite ranks is a feature of a modern governance system.

As a result of the emergence of the objective conditions described above, the desire to provide special autonomy (asymmetrical decentralization) bolstered Papua's development commitments as reflected in Law Number 21 of 2001 concerning Special Autonomy for Papua Province. According to the partnership team, there are several fundamental elements that comprise the law's content, including the following: ${ }^{32}$

1. The arrangement of authority between the government and the Papua Provincial Government, as well as the specific application of authority in the Papua Province;
2. Recognition and respect for indigenous Papuans' fundamental rights, as well as their strategic and fundamental empowerment;

3. Implementing good governance:

a) Participation of as many people as possible in planning, managing, and supervising government administration and development implementation, including indigenous representatives, religious leaders, and women;

b) Implementation of development that is geared toward meeting the basic needs of indigenous Papuans in particular and populations in the provinces of Papua in general, while adhering to the principles of environmental conservation, sustainable development, and purely societal benefit;

c) Government administration and the community's implementation of transparent and responsible development.

4. A distinct and unambiguous division of authority, duties, and responsibilities between the legislature, executive, and judicial branches, and the Papuan People's Assembly (Majelis Rakyat Papua) as the cultural representative of indigenous Papuans endowed with certain powers.

In response to the issue raised above, special autonomy in Papua Province began in 2001 with the enactment of Law Number 21 of 2001 and Law Number 35 of 2008, which mandated the acceleration of development in

32 Ibid., p. 19 
the provinces of Papua and West Papua. The central government's implementation of the policy of special autonomy for Papua and West Papua is a form of accommodation made in order to alleviate various speculations that have arisen as a result of the Papuan people's dissatisfaction with the central government's and regional government's relations thus far. ${ }^{33}$

In contrast to Papua, which gained special autonomy as a result of development. Aceh achieved special autonomy after years of self-separation characterized by armed conflict and identity politics. This circumstance resulted in the initial reform through MPR IV / 1999 tap, which was realized in Law Number 18 of 2001 concerning Special Autonomy for the
Province of Nanggroe Aceh Darussalam, being ineffective because it was not transformed by the Free Aceh Movement's (Gerakan Aceh Merdeka) power into the structure of modern government in the Unitary State of the Republic of Indonesia. ${ }^{34}$

Decentralization is primarily expected to reduce the disparity or economic divide between regions in Indonesia. ${ }^{35}$ However, this gap persists in reality for up to 75 years. The following data demonstrate why decentralization has not yet succeeded. The human development index is one indicator that can be used as a benchmark ${ }^{36}$ in each region. In 2019 it can be seen dimensions, education, and decent living standards in the lowest five provinces, here are the data available: ${ }^{37}$
33 As stated by Vitelis Yumte as Chair of the People's Consultative Assembly of the West Papua Province releases that, the basic framework for the implementation of special autonomy is for the parties. Special autonomy for the parties includes Papuan political elites and the House of Representatives and the President who viewed that Khusu autonomy is the solution. If their point of view is a solution that must be confirmed in implementation. Therefore in special autonomy policies must be given full authority to organize and build themselves with the potential. In real terms this policy has not been sincere because it is influenced by the situation of political upheaval so that the substance made raises doubts by the central government. In the Autonomy Law specifically loaded with various collisions so it is difficult in implementing. This quote was taken from an interview with the Chairperson of the People's Consultative Assembly on November 16, 2011

34 The agrarian principal's fundamental regulations regulate certain specificities, including the Governor of Aceh, the People's Representative Council / Regency / City, the Local Political Party, the Guardian Nanggroe, the Recognition of Indigenous Institutions, Islamic Shari'ah, and the Sharia Court. The Dictum stated that the government recognized and respected special or special regional government units regulated by law; Aceh is a special or special regional government unit associated with one of the characteristics of the Acehnese community's history of struggle: high fighting resilience and power; Lili Romli, Special Autonomy Policy and Implementation in Papua and Aceh, Yogyakarta: Center for Assessment of Data Management and Information, General Secretariat of the House of Representatives of the Republic of Indonesia, and Azza Grafika, 2012, p. V

35 'Economic Growth, Income Inequality And Decentralization In Indonesia', (2016), Volume 20 No. 1, Journal of Kinerja, pp. 53-68

36 UNDP introduced the first human development indicators in 1990. The United Nations Development Programme (UNDP) introduced a new concept for measuring human development called the Human Development Index (HDI). Since then, the human development index has been included in the Human Development Report's annual report (HDR). The HDI elucidates how residents can benefit from development outcomes in terms of income, health, education, and other facets of life.

37 Central Statistics Agency, 2019 Human Development Index 
Table 1. of dimensions of growth, education, and standard of living in five provinces with the lowest human development index from 2017 to $2019^{38}$

\begin{tabular}{|c|c|c|c|c|c|c|}
\hline \multirow{2}{*}{ Provinsi } & \multicolumn{2}{|c|}{ Pertumbuhan Kesehatan } & \multicolumn{2}{c|}{$\begin{array}{c}\text { Pertumbuhan Indeks } \\
\text { Standar Hidup Layak }\end{array}$} & \multicolumn{2}{c|}{$\begin{array}{c}\text { Pertumbuhan Indeks } \\
\text { Pendidikan }\end{array}$} \\
\cline { 2 - 7 } & $2017-2018$ & $2018-2019$ & $2017-2018$ & $2018-2019$ & $2017-2018$ & $2018-2019$ \\
\hline$(1)$ & $(2)$ & $(3)$ & $(4)$ & $(5)$ & $(6)$ & $(7)$ \\
\hline Papua & 0,49 & 0,64 & 1,19 & 1,25 & 3,27 & 2,02 \\
\hline $\begin{array}{c}\text { West } \\
\text { Papua }\end{array}$ & 0,51 & 0,77 & 2,10 & 1,89 & 0,97 & 1,85 \\
\hline $\begin{array}{c}\text { East Nusa } \\
\text { Tenggara }\end{array}$ & 0,67 & 1,01 & 1,46 & 1,31 & 0,97 & 1,60 \\
\hline $\begin{array}{c}\text { West } \\
\text { Sulawesi }\end{array}$ & 0,54 & 0,54 & 1,64 & 0,92 & 1,59 & 1,42 \\
\hline $\begin{array}{c}\text { West } \\
\text { Borneo }\end{array}$ & 0,52 & 0,76 & 2,10 & 1,00 & 0,64 & 1,22 \\
\hline
\end{tabular}

Source : Seccondary Data, processed in 2021

According to the data, Papua and West Papua are part of five regions with low health indices, deplorable living standards, and the lowest levels of education. Although papua has been granted special autonomy, it possesses a variety of specialized characteristics.

In addition to the human development index, we can also see how many poor people based on provinces, data issued by the Central Statistics Agency (BPS) in 2020 in semester 2 (September) there are still several regions that have quite high numbers in terms of population Poor at the provincial level, such as Aceh with $15.43 \%$, Bengkulu with $15.30 \%$, Maluku with $17.99 \%$, West Papua with $21.70 \%$, and Papua with $26.80 \%$. If we compare it with several regions in Java such as East Java and West Java numbers are also still above $10 \%$, but if they see West Java the numbers are still better at 8.43 . Moreover, the figure will be very different if we compare it with the Special Capital Region of Jakarta, which is around $4.63 \%$. Based on the data, we can see that asymmetrical decentralization with ${ }^{39}$ Provincing of special and special autonomy is still not maximally to have an impact on welfare. Even some areas on Java with a variety of more complete infrastructure and geographically closer to the center of power are still high in the figure of the poor. The data presented also shows that massive development is still very thick in the capital city of the state with the high index of human development indices and the small percentage of the poor.

From this point, it is actually clearly one of the serious challenges that accompany regional decentralization and autonomy cars lies in the availability of administrative frames that are able to manage all local diversity because of the heterogeneity of society in Indonesia, both in the socialcultural background variant, economic potential, administrative capacity to be expanded in the charge certain political demands.

Although the space for pluralism in the Unitary State of the Republic of Indonesia is realized through the authority of regional autonomy, as specified in Article 18 of the

38 Statistics Indonesia, Indeks Pembangunan Manusia 2019, Jakarta, pp 51-52

39 Central Statistics Agency, the percentage of poor people by province, https://www.bps.go.id/indicator/23/192/1/persentase-penduduk-miskin-menurut-provinsi.html , accessed on April 202021 
1945 Constitution. $^{40}$ However, when diversity is implemented, it creates a systemic problem and is frequently infused with political elements, making the angle of legal system analysis increasingly difficult to manage uniformly. As a result, certain depictions of decentralization documentation in Indonesia that emphasize policy uniformity actually result in development gaps, as stated in an analysis of articles in Law Number 23 of 2014, which negates its broadest autonomy and adopts the same uniformity concept as New Order local laws. Thus, based on the explanation above, it is possible to deduce the following:

(1) Historically, the dynamics of the trial and error political of decentralization law in our constitutional system has experienced ups and downs, this is seen in Article 18 of the 1945 Constitutional Court explicitly stating that Indonesia is divided into large regions and small areas and has the right to take care of His own house is called autonomy.

(2) Politically, Indonesia has a decentralization model that is used and defined in the constitution according to the pressures and political situation.

(3) Regional autonomy in Indonesia was confirmed philosophically to be based on the principle of "broad autonomy," as stated in Article 18 paragraph (5) of the Republic of Indonesia's Constitution in 1945: "regional government operates with the greatest autonomy, except for government affairs that are statutorily designated as central government affairs."

(4) Sociologically, the serious challenges associated with regional decentralization and autonomy center on the availability of administrative frameworks capable of managing all local diversity, owing to Indonesia's extreme heterogeneity, both in terms of social-cultural background variation, economic potential, and administrative capacity to express demands specific politics.

(5) Juridically, because regional autonomy is the essence of decentralization. The implementation of regional autonomy experiences ups and downs and tends to not maintain its consistency based on the formulation of Article 18 of the 1945 Constitution. Here means there are challenges in terms of juridical to find a meeting point between the historical aspects, philosophy, political and sociological to formulate the model of decentralization in the future.

\section{A. The Conceptualization of Regional Competency-Based \\ Decentralization: The Challenges \\ Raised by Indonesia's Local Government Law}

Based on the paradigmatic context of legal reform described above, one aspect that the author wishes to study and critique is the legal politics of regional competency-based decentralization as part of the concept of decentralization's transformation or evolution. In contrast to Cohen and Peterson's interpretation, there is a section that details the evolution of decentralization as a concept and as a development tool. Cohen and Peterson identified six distinct types of decentralization in their 
identification, which they also used as a classification and approach system: ${ }^{41}$

a. Decentralization form based on the origin of history

The first approach categorizes forms according to their historical antecedents. A historical perspective enables a specialist to emphasize the existence of four fundamental decentralization patterns: French, British, Soviet, and Traditional. Cohen and Peterson argue that this classification system is oversimplifying and analytically deficient.

b. Territorial and functional decentralization of decentralization

The second approach makes a distinction between decentralization forms and hierarchies and functions. Territorial decentralization / region, in this view, refers to the delegation of goods and services to the public produced and provided centrally to units at the regional level in the government jurisdiction hierarchy. While functional decentralization refers to the transfer of center responsibility to units under the government's supervision as well as to units outside the government's control, such as non-governmental organizations or private businesses.

c. Forms that convert to problems and values

This approach identifies decentralized forms associated with the problems presented and the investigators' value-nial. This approach is exemplified by the

41 Decentralization: A Sampling Of Definitions, Working paper prepared in connection with the Joint UNDP-Government of Germany
WeLey decentralization project, which is committed to bringing more effective programs and development projects to rural poor communities. The Berkeley group identified eight distinct types of decentralization, including the following: ${ }^{42}$

a. Devolution;

b. Functional devolution;

c. Organization of Interest;

d. Deconcentration prefectation deconcentration at the level of minister;

e. Delegation of authority against autonomous agents;

f. Generosity or philanthropy; and

g. Marketization / Marketing Process.

The Berkeley group was not interested in illustrating a variety of larger general issues associated with the concept of decentralization when they formatted this collection. This group is devoted to the examination of various relationships between the center and the surrounding area on a sector-by-sector basis (a sector-bysector base). By examining this relationship, they develop a distinctive set of shapes that ensure, project by project, that the development intervention demonstrated is extremely vulnerable to rural communities and threats to it perpetrated by the Central Apparatus and area elites seeking their own interests.

d. Form of service provision

evaluation of the UNDP role in decentralization and local governance, October 1999

42 Fajlurrahman Jurdi, Indonesians Constitutional Law, (Jakarta, Kencana, 2019), p 441. 
This approach focuses on the pattern of administrative or government structures and functions that are responsible for the production and provision of collective services. This strategy distinguishes four types of decentralization: Regional

Government Systems, Partnership Government Systems, Dual Government Systems, and Integrated Government Systems. The disadvantage of this approach is that it is analytic in nature, which is in conflict with the increasing diversity of structural and functional design over the last few decades.

e. Form of state single experience

This approach exemplifies the narrow definition of decentralization that is based on a single country's experience. Delegating responsibility, power, and resources to the central government, in this view, does not constitute decentralization. Decentralization, on the other hand, occurs only when the local government:

(1) is formed by law, in the form of a charter containing legal provisions, which is defined as a government formed by law with the right to sue and be sued;

(2) is a sense of community, consciousness, and solidarity located within jurisdictional bonds that have a clear limit;

(3) is governed by officials and apparatus elected at the regional level;

(4) creates and administers official ordinances or regional regulations governing the functions of public sectors;
(5) officially collects taxes and other revenue in a legal manner; and

(6) attempts to strengthen and to manage the budget, expenditure, and financial calculation systems, as well as to compensate employees, including those in charge of security.

f. Form of decentralization based on purpose

The approach divides decentralization into four categories based on their objectives: politics, space, market, and government. This strategy then focuses on three distinct forms of administrative decentralization: deconcentration, devolution, and delegation.

Political decentralization refers to the delegation of decision-making authority to citizens or selected individuals. Decentralization of space is a term used by regional planners to describe policies and programs aimed at reducing excessive concentration of urban communities in a large city by promoting regional growth poles with the potential to become marketing, industrial, and agricultural centers.

Market decentralization focuses on the establishment of diverse conditions that allow for the production and provision of goods and services through market mechanisms that are sensitive to the choices made by individuals. This type of decentralization has become more prevalent in today's trend toward economic liberalization, privatization, and the abolition of the guided economy. Decentralization 
allows for the production and provision of goods by small and large businesses, community groups, voluntary personal associations, and non-governmental organizations, among others. While administrative decentralization is concerned with the distribution of hierarchical and functional authority between the central and local governments.
The emergence of decentralized forms is based on relationships in the form of authority, responsibility, and resources being transferred from the central government to local governments or other social organizations. In other words, the nature of the relationships between goals and objects, as well as the delegation of authority and responsibility, are all determinants of the decentralization form. To illustrate this, consider the following figure of the nature of relationships and decentralization forms.

Figure 3. Decentralized forms

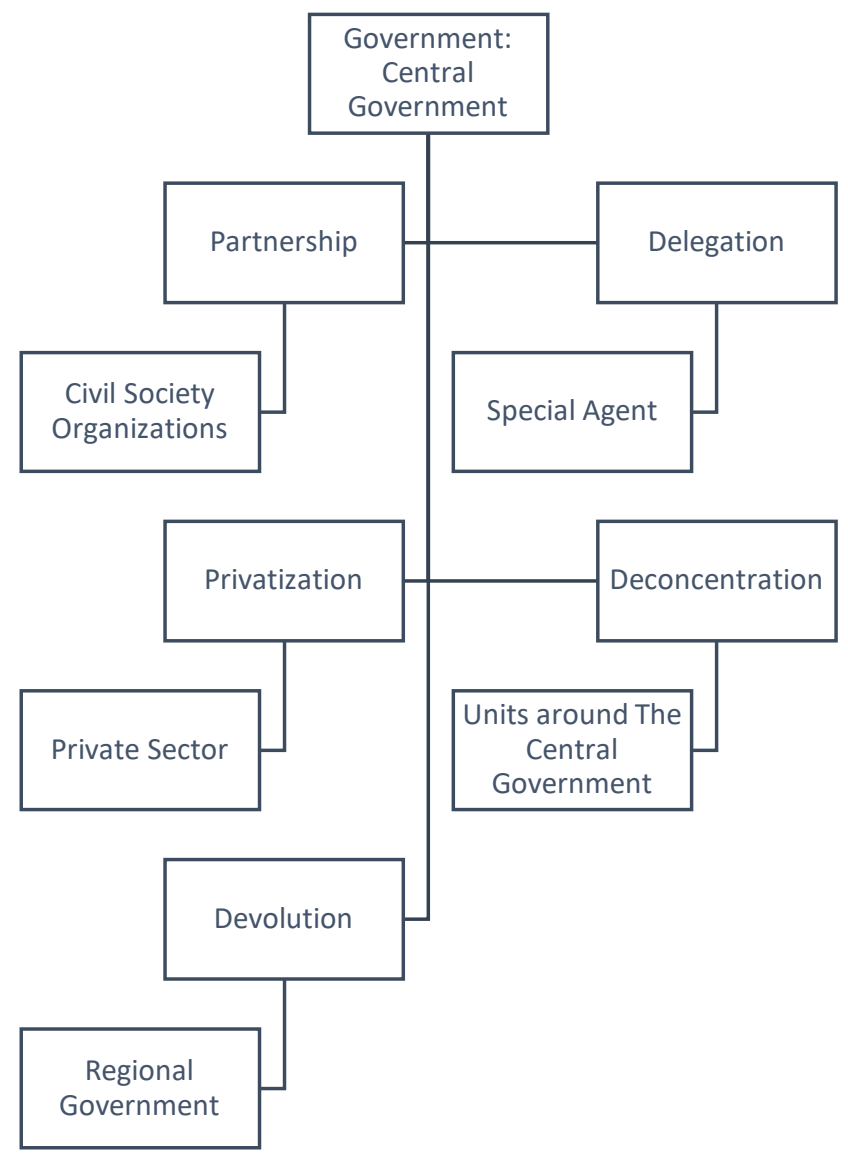

Source: secondary legal material, processed 2021

Measurements regarding the level of implementing decentralization in a country can be taken through measurement of "decentralized degrees". Determining the degree of decentralization can be determined through several factors. These factors are the basis for the author in formulating regional competency-based decentralization points, including:

(a) First, the degree of decentralization can be seen from the function or affairs run by the local government. The more functions that are 
experienced, the higher the degree of decentralization.

(b) Second, it is the type of function of function. In this case there are two types, namely the type of deelegation of General Competence and UltraVires Doctrine. If a regional government has a function of the General Competence delegation, it can be considered a greater decentralization.

(c) Third, it is the type of central government control over the local government. If the control carried out by the government is more repressive, the degree of decentralization is greater than it is preventive.

(d) Fourth, it is related to regional finance related to the extent of decentralization to determine or decide both in terms of revenue and expenditure of local governments.

(e) Fifth, it is the method of establishing a local government. Decentralization degrees will be higher if the regional authority source comes from legislative decisions, not from executive delegation.

(f) Sixth, it is regarding the degree of financial dependence on the local government against the central government. The greater the percentage of financial assistance from the central government compared to regional original revenues, the higher the dependence which also leads to the low degree of decentralization.

(g) Seventh, it is the magnitude of regional government areas. There is an assumption when the increasing area is the greater the degree of decentralization, because local governments can overcome the dominance of power from the central government.

(h) Eighth, it is a political factor of the party. If politics at the local level is still dominated by national political organizations, the degree of decentralization is considered low compared to politics at the local level dominated by local political parties. ${ }^{43}$

The eight decentralized descriptive measurement factors served as the primary determinant of regional competency-based decentralization. Decentralization in Indonesia is based on international experiences, which are then elaborated in the constitutional articles. To optimize the legal politics of decentralization in Indonesia, it is necessary to conduct decentralization conceptualization, bearing in mind Cohen and Peterson's view that the concept of decentralized degree of decentralization is influenced by: a small / or a large number of authorities, the conditions of regional government, government function, and regional financial authority. ${ }^{44}$

These factors are the basis for the capacity-based decentralization and regional competence, one of which has been opened in the provisions of Article 31 and Article 48 of Law Number 23 of 2014 concerning the Regional Government that in the implementation of the decentralization is carried out by the regional settings for:

a. ensuring the effectiveness of regional government implementation;

44 M.R. Khairul Muluk, The Concepts of Decentralization and Government, (Itspress, Surabaya, 2009), p. 14 

b. accelerating the growth of community well-being;
c. accelerating the process of enhancing the quality of public services;
d. enhancing the governance quality;
e. enhancing national and regional competitiveness; and
f. preserving the uniqueness of regional customs, traditions, and culture.

Regional arrangements may take the form of regional formation or regional reorganization. Indeed, according to Cohen and Peterson, Law Number 23 of 2014 on Local Government has paved the way for the development of decentralization models based on how the area was formed. It is simply that it is still limited to the aspects of regional formation and regional adjustments that are discussed in detail in the articles and does not include the competency-based decentralization model or regional capacity. On the other hand, this regional competence cannot be divorced from the consequences of autonomy, as defined in Article 18 paragraph (1) of the 1945 Constitution, which provides that the provincial government, district regions, and cities regulate and manage government affairs in accordance with the principle of autonomy. The competency of this area can be described in terms of regional competency parameters within the framework of regional government, which is composed of several elements based on the initial viewpoints desired, such as:

a. Geography, including: the location of the capital; hydrographic; and disaster insecurity;

b. Demographics, including: quality of human resources; and population distribution;

c. Security, including: General Criminal Action; and social conflict; d. Socio-political, custom, and tradition, including: community participation in general elections; social cohesiveness; and community organizations;

e. Economic potential, including: economic growth; and the superior potential of the region;

f. Regional finance, including: original regional income capacity; potential original income prospective preparation area; and financial management and regional assets;

g. Government organizing capabilities, including: accessibility of basic education services; accessibility of basic health services; accessibility for basic infrastructure services; The number of state civil apparatus employees in the parent area; and design planning spatial plans for the preparation area;

According to the competency-based decentralization paradigm and the area's capacity, this is actually a form of decentralization that is currently occurring in Indonesia, namely asymmetrical decentralization. Where the decentralization model is as stated in the sociological foundation, resulting in the concepts of special autonomous regions, administrative areas, and special regions. Where these conditions frequently arise as a result of political and social pressure. Thus, the presence of capacity-based decentralization and regional competence creates an alternative model for regional government management that prioritizes local development without resorting to political pressure or social conflict. The following table illustrates the distinctions between asymmetrical decentralization, capacity- 
based decentralization, and regional

competence:

Table 2. Capacity-Based Decentralization Concepts and Regional Commerce with Asymmetrical Decentralization are Summarized.

\section{INDICATOR}

\section{ASYMMETRIC DECENTRALIZATION}

\begin{tabular}{|c|c|c|}
\hline & & \\
\hline Deeper aspects & $\begin{array}{l}\text { Korbinwas, Politics, Authority, } \\
\text { Institutional, Finance }\end{array}$ & $\begin{array}{c}\text { Korbinwas, Politics, Authority, } \\
\text { Institutional, Finance }\end{array}$ \\
\hline Shape / Output & $\begin{array}{l}\text { - Special Autonomy: Special } \\
\text { Regions and Special Regions } \\
\text { - Aceh, } \\
\text { - Papua, } \\
\text { - West Papua, } \\
\text { - Special Capital Region of } \\
\text { - Jakarta, and } \\
\text { - Special Region of Yogyakarta }\end{array}$ & $\begin{array}{c}\text { Kluster of the immediate area: } \\
\text { Group A area } \\
\text { Group B area. } \\
\text { Group C area. }\end{array}$ \\
\hline Cause / Input & $\begin{array}{l}\text { - Conflict of Interest } \\
\text { - Demands / Submissions of } \\
\text { Asmetrical Forms }\end{array}$ & $\begin{array}{l}\text { Noted for The Elements. } \\
\text { - Geography; } \\
\text { - Demographics; } \\
\text { - Security; } \\
\text { - Social politics, customs, and traditions; } \\
\text { - economic potential; } \\
\text { - Regional Finance; and } \\
\text { - Government administration } \\
\text { capabilities. }\end{array}$ \\
\hline Legal basis & $\begin{array}{l}\text { Relational } \\
\text { Article 18, Article 18A, Article } \\
\text { 18B }\end{array}$ & $\begin{array}{l}\text { Hirarchical - relational } \\
\text { 1. Preamambule, } \\
\text { 2. Article } 1 \text {, } \\
\text { 3. Article } 18,18 \mathrm{a}, 18 \mathrm{~b} \text { (Regional } \\
\text { Government) } \\
\text { 4. Article } 23 \text { (Finance); } 27 \text { (Tenaker); } 28 \\
\text { (ham); } 29 \text { (religion); } 31 \& 32 \text { (dikbud); } 33 \\
\text { (Economy); } 34 \text { (poverty) }\end{array}$ \\
\hline
\end{tabular}

DECENTRALIZATION-BASED CAPACITY AND REGIONAL COMMITTANCY

Korbinwas, Politics, Authority, Kluster of the immediate area:

Group A area

Group B area.

Group $\mathrm{C}$ area. 
administrative autonomy indicators, but also of potential based on social-cultural background variants, economic potential, and administrative capacity to be expressed in the charge of other political demands. At the very least, a decentralization model based on regional capacity can provide regional autonomy in regulating its natural resources. This regional competency base also serves as the foundation for determining whether regions operating on autonomous frames are capable of pursuing backward development and welfare retardation in accordance with their capacity, not with a model approved by the central government.

To begin, the author's concept of regional competencies is to adopt regional feasibility and competency assessments in accordance with Law Number 23 of 2014 on Regional Government. Despite the analogical interpretation of the terms "Regional Competency" and "regional expansion / adjustment," the initial design of the region's expansion / incorporation into the regional arrangement scheme is philosophically sound. ${ }^{46}$ The implementation, both regional competencies and regional expansion / adjustments, is related to the prudential principle, the organization of natural asset maps and natural resources, the maintenance of public relations, and the assessment of potential horizontal-vertical conflict. These assessments were made on the assumption that future expansion / adjustment of the area would be able to make it competent or incapable of accommodating the formatted otnomy in the Indonesian legal system. On the other hand, the regional arrangement model exemplifies decentralization in action, ${ }^{47}$ where aiming:

46 Academic Manuscripts of Law 23 of 2014 concerning Local Government a. "Determining the effectiveness of regional government implementation;

b. increasing community welfare at a faster rate;

c. accelerating the process of improving the quality of public services;

d. enhancing the governance quality;

e. enhancing national and regional competitiveness; and

f. preserving the uniqueness of regional customs, traditions, and culture."

The disadvantages, in terms of regional expansion / adjustment, are that there is no authentic nomenclature for "regional adjustments" based on legislation. The illustration of the befunctional adjustment is solely for the purpose of:

a. regional;

b. change of regional names;

c. giving names and changes in the name of the form of earth;

d. the transfer of the capital; and / or

e. changes in the name of the capital city."

As a result, the aforementioned concept of regional adjustments effectively ends regional competency-based decentralization, as anticipated by Article 18 of the Republic of Indonesia's 1945 state law. As demonstrated above, the political politics of regional competency-based decentralization can be interpreted philosophically, sociologically, and historically, as evidenced by the presence of several models of parameters required in decentralized settings, including geographic parameters; demographics; security; socio-political, custom, and tradition; economic potential;

47 See article 31 Act Number 23 of 2014 concerning Local Government 
and regional finance. As a result, amendments to regional government laws are required to incorporate the principle of broad autonomy and to provide a classification of decentralization models based on regional competency parameters affecting the extent to which the area's task and authority and the appropriate policies / programs for the region's center are decentralized.

\section{CONCLUSION}

Based on the research focus and the explanations that have been described by the author, it can be concluded that based on the analysis with historical, philosophical, and sociological approaches, it can be said that the implementation and development of regional implementation is strongly influenced by various aspects other than the legal factor itself. Challenges to the development of decentralization implementation arrangements in Indonesia are possible to be based on regional capacity which is based on several aspects such as geography, security, socio-politics, economic potential, regional finance, government organizational capability. This policy aims to enable decentralization to be carried out closer to local conditions in the regions. A further challenge is regarding the regulation of the policy in the legislation.

\section{REFERENCES}

\section{Book}

Abdurrahman (Editor), Some Thoughts about Regional Autonomy. Media Sarana Press., Jakarta. 1987

Agung Djojosoekarto, et al, Papuan Special Autonomy Performance, (Jakarta: Updates on the Partnership for Governance in Indonesia, 2008)

Bagir Manan, Welcome to The Arising of Regional Autonomy, (Legal Study Center of Law Faculty, Indonesian
Islamic University 2001

Fred Isjwara, Introduction to Political

Science,(Bandung:Bina Cipta, 1974)

Henry Maddick, Democracy Decentralization, and Development, (London: Asia Publishing House, 1966)

Hesti Armiwulan, 'Legal Politics of Regional Government Based on Law Number 23 of 2014 in Terms of Institutions and Relations of The Authority of The Regions' in Inna Junaenah Et. Al, Decentralization or recentralization? Regional Government Law Politics According to Regional Government Law No. 23 of 2014, (State Policy Study Center, 2015)

John M Cohen and Stepen B. Peterson, Adminitrative Desentralization, (Kumarian Press, 1999)

M. Laica Marzuki, Strolling in the Law, Secretariat General and Registrar's Office of the Constitutional Court of the Republic of Indonesia, Jakarta, 2006

M.R. Khairul Muluk, Decentralization and local government, (Malang: Bayumedia Publishing, Cet 2, 2007)

M.R. Khairul Muluk, The Concepts of Decentralization and Government, (Itspress, Surabaya, 2009)

M Rifqinizamy Karsayuda, Establishment of Local Political Parties in The Unitary State of The Republic of Indonesia, (Malang: UB Press, 2013)

Mohammad Hatta, Towards Indonesian independence: 1932-volume I, (Jakarta: Bulan Bintang, 1976)

Muhammad Noor, Understanding Indonesia's Decentralization, (Interpena, 2012),

Muhammad Yamin, Proclamation and Constitution of The Republic of Indonesia, (Gahlia Indonesia, 1982) 
Ni'matul Huda, Law of Regional Government, (Bandung: Nusamedia, 2010)

Sirajuddin and Et Al., Regional Government Administration Law, (Malang: Setara Press, 2016)

Solichin. A. Wahab, The Future of Regional Autonomy: Social, Economic, Political Studies, to Create Synergy in Regional Development, (Surabaya: SIC Publishing, 2002)

Sunaryati Hartono, Legal Politics Towards A National Legal System (Alumni, 1991)

\section{Journal}

Afif Syarif, 'Release of Regional Autonomy in the Formulated System of the Republic of Indonesia: Review of Legal History of Regional Government' (2013) Vol. 6 No.7 Journal of Inovatif, p. 48

Haryanto, 'Future of Decentralization Politics in Indonesia: An initial study', (2016) Volume 9 No. 2 Government: Government Journal, p. 115.

Khotman Annafie, 'Institutional Special Autonomy in Preserving Cultural Values in the Province of Yogyakarta Special Region', (2016) Volume 3 No. 2, Journal of Kebijakan Pemerintah \& Publik, p.305

Lestari Agusalim, 'Economic Growth, Income Inequality and Decentralization In Indonesia', (2016), Volume 20 No. 1, Journal of Kinerja, pp. 53-68

Mardyanto Wahyu Tryatmoko,

'Democratization of Problems in The New Post-Order Era of Asymmetrical Decentralization', (2012), Volume 38 No. 2, Journal of Masyarakat Indonesia, pp. 269-296

Suharno, 'A Critical Examination of Law No. 32 of 2004 Relating to Regional
Government', (2004), Volume 1 No. 2, Journal of Civics, pp. 168-180

Wasisto Raharjo Jati, 'Inconsistency in Indonesia's Regional Autonomy Paradigm: Cultural and Decentralization Issues', (2012), Volume 9 Nomor 4, Journal of Konstitusi, pp. 743-769

\section{Statute}

The National Law of the Republic of Indonesia 1945

Law Number 18 of 1965 concerning Regional Government Principles

Law Number 5 of 1974 concerning the Principles of Government in the Region

Law Number 22 of 1999 concerning Regional Government

Law Number 32 of 2004 concerning Regional Government

Law Number 23 of 2014 concerning Regional Government

\section{Online Source}

Central Statistics Agency, the percentage of poor people by province, https://www.bps.go.id/indicator/23/19 2/1/persentase-penduduk-miskinmenurut-provinsi.html, diakses pada 20 April 2021

\section{Other}

Central Statistics Agency, 2019 Human Development Index

Decentralization: A Sampling Of Definitions, Working paper prepared in connection with the Joint UNDPGovernment of Germany evaluation of the UNDP role in decentralization and local governance, October 1999

Academic Manuscripts of Law 23 of 2014 concerning Local Government 
Minutes of the Workers Meeting of the

Republic of Indonesia's People's Consultative Assembly (MPR) 1945

People's Consultative Assembly of the

Republic of Indonesia, 2002 